\title{
The Effects of Using Multimodal Approaches in Meaning- Making of 21st Century Literacy Texts Among ESL Students in a Private School in Malaysia
}

\author{
Malini Ganapathy \\ School of Languages, Literacies and Translation, Universiti Sains Malaysia, 11800 Penang, Malaysia \\ Saundravalli A/P Seetharam (Corresponding author) \\ Fairview International School, Tingkat Bukit Jambul Satu, 11900 Bayan Lepas, Penang, Malaysia \\ E-mail: saundravalli@gmail.com
}

Doi:10.7575/aiac.alls.v.7n.2p.143

URL: http://dx.doi.org/10.7575/aiac.alls.v.7n.2p.143
Received: 14/11/2015

Accepted: 17/01/2016

\begin{abstract}
In today's globalised digital era, students are inevitably engaged in various multimodal texts due to their active participation in social media and frequent usage of mobile devices on a daily basis. Such daily activities advocate the need for a transformation in the teaching and learning of ESL lessons in order to promote students' capabilities in making meaning of different literacy texts which students come across in their ESL learning activities. This paper puts forth the framework of Multimodality in the restructuring of the teaching and learning of ESL with the aim of investigating its effects and students perspectives on the use of multimodal approaches underlying the Multiliteracies theory. Using focus group interviews, this qualitative case study examines the effectiveness of ESL teaching and learning using the Multimodal approaches on literacy in meaning-making among 15 students in a private school in Penang, Malaysia. The results confirm the need to reorientate the teaching and learning of ESL with the focus on multimodal pedagogical practices as it promotes positive learning outcomes among students. The implications of this study suggest that the multimodal approaches integrated in the teaching and learning of ESL have the capacity to promote students' autonomy in learning, improve motivation to learn and facilitate various learning styles.
\end{abstract}

Keywords: Multimodal Approaches; Multiliteracies; Monomodal; Flipped Classroom; Literacy; Multimodal texts; Ipad

\section{Introduction}

The dynamic nature of Information and Communications Technology (ICT) has largely affected the way people today live, communicate, work and play because elements of computers are found in almost everything (Frost, 1999). Students today are greatly exposed to mobile devices and the World Wide Web which enable them to acquire facts and gain access to various sources of knowledge in a mere touch of a screen.

"There is now a growing consensus that "real life" reading should be the starting point rather than the ending point of teaching initial literacy and that skills such as phonics should be used as a tool in helping learners understand the "print" they see around them. (Wrigley \& Guth, 1992)

As seconded by Wrigley \& Guth (1992), the dynamic nature of language teaching does not end at learning only grammar, phonics and vocabulary but also involves practical learning of interpreting everything around students today. According to Manan (2012), the fast diffusion of ICT into our daily lives urge for a shift in the literacy pedagogy from conventional teaching approaches to contemporary teaching approaches by enabling integration of ICT into daily lessons. Today's students are greatly exposed to Multimodal Approaches (MMA) practices on a daily basis which leads to mounting acceptance of a wider range of literacy practices involving both print and digital technologies (Kaur \& Ganapathy, 2013).

Therefore, the changing nature of students' exposure and interest in literacy learning has triggered the researcher to analyse the benefits of the MMA in the teaching and learning of ESL. Ganapathy (2011) expresses her view that Malaysian schools are considered to be limited to conventional teaching approaches in classroom confined settings. It is common for ESL educators to utilize print-based texts that are made available to educators in schools as all students have access to these textbooks via the existing Textbook Lending Scheme (Mohd Ghani, Mahmood, Abdul Halim \& Rajindra, 2013). Therefore, this study aims to investigate if the Multimodal Approaches are beneficial to the students of ESL in meaning-making when confronted with various multimodal literacy texts as well as the students' perceptions on the use of Multimodal Approaches in the teaching and learning of ESL. 


\section{Review of related literature}

\section{$2.121^{\text {st }}$ Century Literacy}

Occupations now demand for multi skilled employees with higher level of literacy compared to the past (Mikulecky \& Kirkley, 1998). Mikulecky \& Kirkley (1998) emphasise on communicational skills, computational skills and skills of operating technical tools as the most significant abilities an employer should possess, mainly to facilitate the information processing in workplaces.

Current generation of students known as Digital Natives have grown in a technology filled environment as they are flexible to changes and are accustomed to ICT language (Prensky, 2001 as cited in Carroll, 2011). Digital Natives are also skilled in using ICT innovatively and creatively (Considine, 2009 as cited in Carroll, 2011). In contrary, most teachers who teach current generation of students are Digital Immigrants as they face challenges in adapting to changes and understanding ICT language (Prensky, 2001 as cited in Carroll, 2011).

Thus, rapid growth of technology is one of the main root causes in the shift from monomodality to MMA in the teaching and learning of ESL. Thus, urgent change needs to be made to the way literacy is being taught in schools and teaching approaches need to be shifted from monomodal to MMA.

\subsection{Students' Motivation in Learning ESL}

Students' motivation and attitude are often linked to the learning of English as second language. Falk-Ross (2014) suggested that students reading difficulties will be motivated to read with the use of multimodal texts as they are more easily comprehended with the aid of other supporting modes such as visuals and sounds. However, the scenario is the opposite when teachers use print-based texts with focus on textual mode.

A recent case-study on the effects of using multi-modal literacy has proven that immense amount of learning takes place amongst students when they were exposed to a range of multimodal tasks related to reading and writing (Walsh, 2010). According to Walsh (2010), students involved in the case studies were greatly involved in the tasks provided by viewing, searching for information and responding when they were given a multi-modal task to work on. Multimodal texts enrich students' learning experiences and provide them a wider grasp of knowledge and skills and this is supported by Walsh (2010). On the other hand,

"Students' personal aspirations and vocations cause their conceptions of knowledge and learning to be different from each other. Learning approaches are chosen according to their motivations and reasons for learning, so they may be deep or surface students who are either active or passive. "(Pillai \& Vengadasamy, 2010)

As Pillai \& Vengadasamy (2010) have mentioned, students' inclinations and personal targets affects the lessons and determines their learning.

\subsection{Theory of Multiliteracies}

With the changing nature of literacy in mind, The New London Group came together and came up with the Pedagogy of Multiliteracies in 1996. The main idea of Multiliteracies is the interrelationship between diverse modes of meaning and brings about the move from print-based texts to acknowledge the changing nature of literacy.

\subsubsection{Three Elements of Design}

The New London Group (1996) presented three main elements of design to describe the activities as individuals identify, read and produce new text using varying semiotic codes. These three elements of design allow individuals to create patterns of meaning from the multiliteracies available in the surroundings and texts: Available Designs, Designing and Redesigned. "Design" is used to describe forms of meaning and "Designs" too includes a set of conventions associated with semiotic activity that take place in a social place.

Available designs refer to grammars of language, styles, genres, dialects, voices and various semiotic systems from which we gain as designers (Cope \& Kalantzis, 2000).

Designing on the other hand refers to reading, seeing and listening which facilitates in the transformation of the available resources of meaning. It can also mean new use of old existing materials.

The third element, Redesigning denotes the production of new meaning which is remade by the meaning-makers themselves. The redesigned meanings are then identified as the new resources of meaning making which is also known as the Available Design (The New London Group, 2000). From this, it can be derived that these three elements of design complement and affect one another.

In order to communicate different forms of meaning found in the Available Designs and Redesigned, language is needed. Thus, the need for a metalanguage that describes escalated and indeed it was the main objective of the Multiliteracies Project to develop educationally accessible functional grammar that is metalanguage used to describe meanings in various domains. According to Cope \& Kalantzis (2000), the main purpose of metalanguage is to identify, contextualise and differentiate between texts including the textual and visual. 


\subsubsection{Conceptual Framework}

This study's conceptual framework takes into account six major modes to describe and explain patterns of meaning which are the metalanguages or grammars of meaning-making that encompass Linguistic Design, Visual Design, Audio Design, Gestural Design, Spatial Design and the Multimodal Design (The New London Group, 1996).

The Linguistic Design includes meaning-making through writing and reading various types of texts and structures, cohesion, modality, textual features, vocabulary, figurative elements, grammars, syntax, semantics. Visual Design refers to meaning-making based on colours, perspectives, size, shape, vectors and backgrounds. Audio Design refers to meaning-making through interpretation of music and sounds. Gestural Design refers to the movements of the body, proxemics, kinetics, gesture, emotional effect, presentation and behaviour. Spatial design is greatly related to the interpretation of spacing, proximity, layouts, and relationships within and across texts, and within the physical environment. The most significant Design of all six Designs is the Multimodal Design. Multimodal Design refers to meaning-making via interpretation of two or more modes of Designs.

The six designs are vital in students' process of learning as they interact with various forms of texts in their daily lives which takes into account the main aims of this study that are to examine the relevance of MMA to the students of ESL in meaning-making, to determine whether students benefit from MMA and to analyse students' perceptions on the use of MMA in meaning-making via the use of MMA in the teaching and learning of ESL.

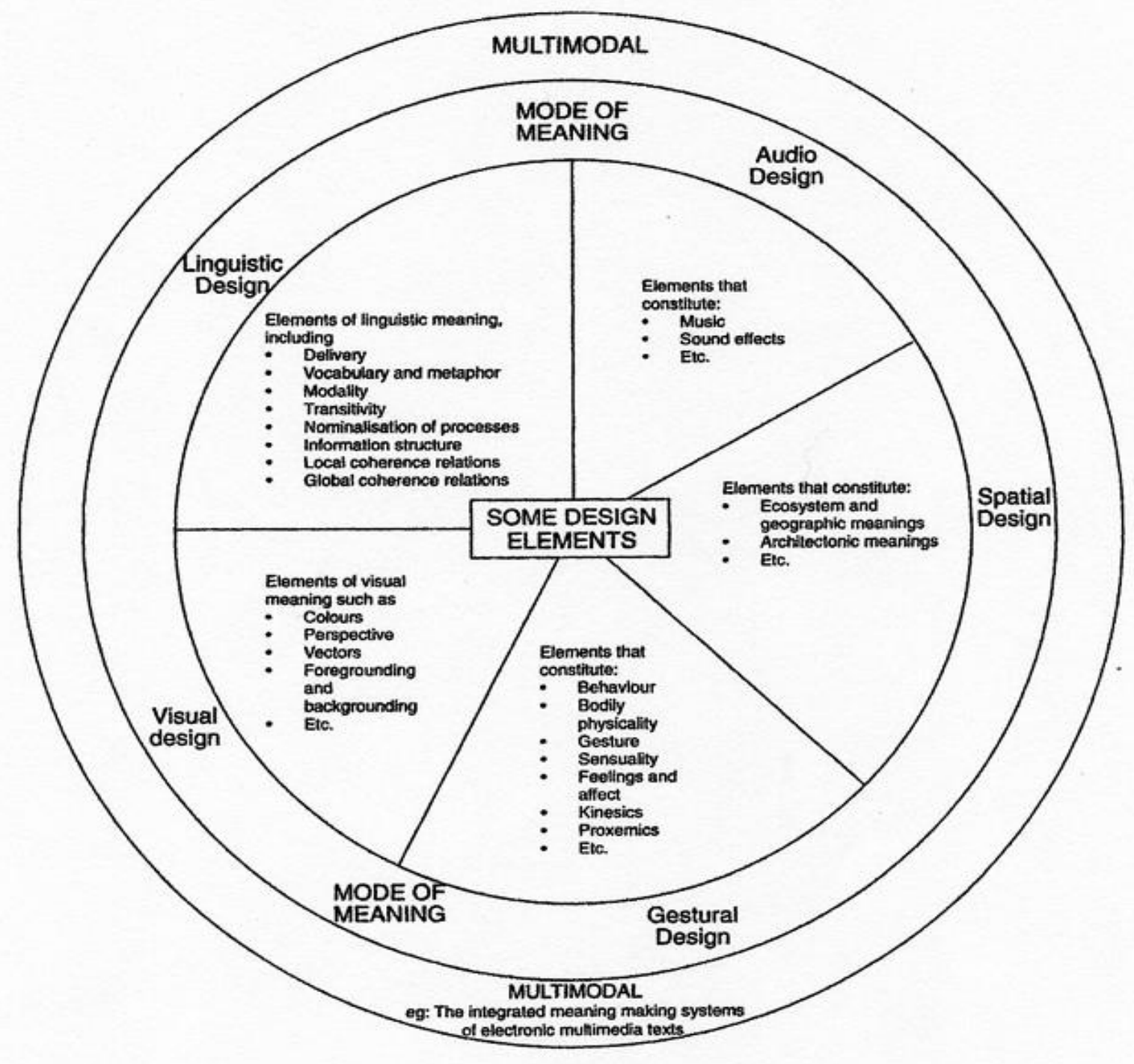

Figure 1. Multiliteracies Framework

Source: adopted from Rush, 2003.

\subsection{Multimodal Approach}

Key to multimodal perspectives on literacy is the basic assumption that meanings are made (as well as distributed, interpreted, and remade) through many representational and communicational resources, of which language is but one (Kress \& van Leeuwen, 2001 as cited in Jewitt, 2008). 
In the past, every field of study tended to focus on one mode of meaning and there has not been much emphasis put on various modes of meaning due to the heavy usage of print-based texts in daily routines. In contrary, current globalisation and rapid development of technology have shed light on the prospects of bringing all means of meaning making under the theory of Multimodality (Kress, 2009).

Besides that, researches reveal that positive changes in learning takes place through the use of visual and verbal multimodal learning (Fadel, 2008, p. 12 as cited in Sankey, Birch \& Gardiner, 2010). In other words, students perform better when learning takes place in accordance to their learning styles and preferences and MMA emphasizes on differentiation of learning experiences. According to Jewitt (2008), it is crucial for schools to avoid teaching static grammar of modes as it restricts the power of transformation and contextualizing among students. She too emphasises that the boundaries between modes are blurred when complex multimodal texts are used in meaning-making.

\subsection{Past studies on MMA in ESL}

The Theory of Multiliteracies has been around since the year 1996 paving way to the emergence of multimodality and multimodal approaches in the teaching and learning process. There are a range of studies carried out in the past to examine multimodality and its approaches in real classroom situations.

In a study carried out by the United Kingdom Literacy Association, it is found that students of 3-16 years old use a range of literacy skills when reading texts on-screen. Findings from this study have shown that the reading of texts-on screen involves radial browsing which is relatively different from linear reading of print-based texts. The researchers of this study affirmed that students were able to search through various modes of design to retrieve information and this process of reading can never be assessed similarly to that of reading print-based texts (Bearne et al, 2007 as cited in Walsh, 2010).

In 2004, a different study was carried out in Malaysia investigating the use of Multiliteracies approach which was carried out in several selected schools in Perak. This study has reported that the teachers involved in this study confirmed and supported the multiliteracies approach as an effective pedagogical approach. Students who participated in this study were found enjoying the lessons more than their usual traditional lessons (Ahmad Suhaimi, 2004 as cited in Kaur \& Ganapathy, 2013).

Over a period of two years (2003-2004), a total of 20 teachers joined the Queensland Department of Education carried out the Queensland Learning by Design Project. Through this Project, teachers reflected on their existing teaching practices and considered Learning by Design as a new pedagogical framework (Neville, 2005). As a result of this project, teachers found students being highly collaborative and participative.

In a recent study carried out in a local Chinese school on the use of Multiliteracies to engage learners to produce learning, Ganapathy (2014) found that students were positively engaged in multimodal literacy practices revealing teachers' positive comments and students' improved interest on their ESL writing lessons. It is found that the learning outcomes were productive and students were active and highly motivated.

All these studies has one in common, the positive outcomes of MMA and Multiliteracies in developing students' literacy skills as well as the emphasis on the urgent need for Malaysian schools to shift from traditional ESL classroom settings and resources to MMA based ESL classrooms. Although various studies have been carried out locally and internationally to examine the use of Multiliteracies and MMA in ESL lessons, this case study is different in settings and research methods as it is aimed to discover more of students' perspectives and perceptions on the use of MMA in the teaching and learning of MMA.

\section{Methodology}

\subsection{Research Design}

A case study design is useful when the focus of the study is to answer "how" and "why" questions, the behaviour of those involved in the study cannot be altered, contextual conditions are the required for the purpose of the study or when the boundaries are not clear between the phenomenon and context (Yin, 2003 as cited in Baxter \& Jack, 2008). This research employed case-study research design as it is suitable for the context of this case study and qualitative methods have been chosen to address the research questions. The behaviours of those involved in this study were maintained at their original contextual conditions and the issue chosen was real.

\subsection{Research Questions}

The study was guided by the following research questions:

1) To what extent are the Multimodal Approaches beneficial to the students of ESL in meaning-making?

2) What are the students' perceptions on the use of Multimodal Approaches in the teaching and learning of ESL?

\subsection{The Sample}

The participants of this case study are ESL students from a local private school with English as its medium of instruction. The Principal requested that the researcher preserve the identity of the school where the research will be conducted. Hence, the school is labelled as school A throughout this study.

Participants were chosen using the purposive sampling technique based on certain common characteristics. Participants chosen to participate in this case study have English as their second language. They have all experienced MMA in their ESL lessons. They have access to the Internet, Flipped Classroom websites and Ipads/laptops for use during school 
hours and lessons which guaranteed integration of ICT tools in their ESL lessons. The sample contained 15 participants with 5 in each focus group.

\subsection{Research Instrument}

This case study employed semi-structured focus group interviews as the research instrument. This instrument was used because it is a very flexible technique for small scale research (Drever, 1995 as cited in Pathak \& Intratat, 2012). It is one of the most apt methods of data collection based on contexts which are not directly observable such as the context of this case study where learners' preferences towards MMA in ESL classroom are to be investigated based on their personal experiences. The interviews were carried out in a face-to-face manner as it is claimed to be one of the most effective way to ensure cooperative from the participants and at the same time clarify matters or issues that needs to be rectified (Hopkins, 2002 as cited in Ganapathy, 2007).

Questions posed in the focus group interviews were open-ended and semi-structured to allow participants to express their thoughts freely and openly without having to fit into pre-determined categories. Questions were rephrased and orally administered to reflect specific individual experiences instead of generalized thoughts in order to help the researcher to gain in depth information. The length of the interview was not pre-set. An advantage of employing the semi-structured focus group interview is that it allows the interviewer to have some control and power over the interview and promotes flexibility (Nunan, 1992 as cited in Ganapathy, 2007).

\subsection{Procedure}

This study employed a qualitative approach whereby data was collected from 15 students of a private school through sessions of semi-structured focus group interview. Each focus group consisted of 5 students and each session lasted about 45 minutes to an hour. Every group has been given a particular time slot to avoid clashes with their school routines. The interview schedule was divided into two to effectively elicit answers from students to effectively answer the research questions. Data collected was immediately transcribed to avoid overloading the researcher with extensive amount of data. Data collected were collected and analysed based on the Grounded Theory. In the open coding stage, identification of concepts took place and raw data were sorted and categorised into conceptual categories. Following this, the conceptual categories were grouped into much abstract and broader categories. The final stage of coding was the selective coding stage when a core category was identified. Using these, a few themes emerged which served as the answers to the research questions of this case study. The themes emerged from this study are the learning styles of the students, self-directed learning, learners' engagement and motivation as well as learners' positive outlook on the use of MMA in the teaching and learning of ESL.

\section{Results}

\subsection{Results of the Students' Perceptions on the Use of MMA in Learning ESL}

In students' respective focus groups, they were asked about the amount of time spent on their mobile devices and gadgets in and out of school on a daily basis. This question was aimed to discover the degree of exposure to technological devices and online activities among these students. Generally, all students involved in the focus-group interview sessions admitted to a minimum of 1 hour and a maximum of 8 hours of usage daily including in and out of school activities. The students commented that they commonly use their devices to complete school tasks, browse social media and use search engines to seek information necessary for their school tasks. All of them admitted to owning a smartphone and social media accounts especially Facebook.

When asked about their comfort level when using online resources or mobile applications that are aimed to help improve their skills of English language, many of them responded unanimously that they felt very comfortable using these online resources and applications which were given to them by their English teacher. These students are comfortable using online resources as they have prior knowledge on ICT tools which led them to seamlessly navigate through the resources provided. However, some of them were of the opinion that mobile applications were much difficult to be learned as they needed step by step guidance and more time in order to familiarise themselves. One of the students' response:

"Since I know how to surf the internet quite easily, and I know how to cite and summarise, I feel very comfortable using them. But when it comes to applications, it would be in different formats, so I'm not quite sure. However, when I'm taught how to use it, it is easy for me." $(E: F G 1)$

A different student's response:

"I'm comfortable using them. Applications may be slightly difficult to work with in the beginning." (B:FG2)

Generally, all students were comfortable with online resources provided to them by their English teacher as they have grown accustomed to it and some of them commented that they need time to play around with the applications to be more fluent in using them. Therefore, it is found that students are positive minded in accepting the use of online resources and applications. They are enthusiastic in learning English with the use of gadgets and technology in the class when compared to using books. A few of them were heard commenting: 
I feel comfortable using all those websites because it's easier compared to books because we have to find resources in book by reading it but in the internet all the information are easy to be found and summarise.(B:FG2)

Ifeel comfortable because it is easier than reading a book.(E:FG2)

The students were then asked to comment on the question, "Have you used Ipads/laptops or the World Wide Web in the classroom to help you with your study of English as Second Language? How useful was it?" All students commented positively and some expressed their experiences on the use of gadgets and the World Wide Web in their English lessons.

Some of the students' responses:

\begin{abstract}
"In my perspective, using the Ipad and laptops helps me in English because I can find a word that I don't fully understand, search it and find its deeper meaning"(A:FGI)
\end{abstract}

"It helps me a lot for if I don't know something I can go online to search for it. For an example, if I need to find information about a character that I would like to write in my essay, I could go online and it's useful."(C:FG1)

The students were heard commenting on the effectiveness and the usability of the gadgets and the World Wide Web in facilitating their learning process of ESL in the classroom. They referred to the gadget and the World Wide Web as being useful in correcting their mistakes, enhancing their vocabulary and for searching extra information. This reflects students' abilities to self-correct and self-initiate language learning. The use of MMA in ESL class prepares the students to be active citizens who are skilful and secure in identities (Kalantzis and Cope, 2005 as cited in Ganapathy, 2007).

The next question required the students to comment on the frequentness of gadgets use in the class and their preferences. They all commented that their teacher often uses gadgets in the class and they would prefer their teacher to use such devices and technologies more often during ESL lessons.

One of them stated, "I would like her to use it more often because there are more things that can be done with an Ipad. For an example, paper based activities will not allow us to make videos but we can create videos using Ipad. If we need to use a video, we can click the link and put it in (C:FG1)." Many of them added that Ipads and laptops are frequently used for group work, mind-mapping and note-taking which eased their burdens of having to jot down in papers or books. Another student commented "The teacher uses gadgets often and I would like it more often because it makes it easier to do work. I could share one document with everybody and know they contributing or not. It makes learning fun and easy too (B:FG1). Thus, it can be noted that team based tasks are easily executed with the use of gadgets in the classroom and ensures contribution from every member of the team. When asked if they face difficulties in using Ipads or laptops to learn in the class, all of them positively commented that they hardly face any difficulties but if they do, the problems are easily rectified.

The next question is aimed to discover the students' need for teacher's assistance in the learning of ESL with the availability of Ipads and laptops in the class. All students claimed that they do need the teachers' guidance but at a much minimal rate when compared to lessons without the use of technology. They stated that though Ipads and laptops are helpful in many ways, they still require the teachers to counter check and proofread their work as noted in student A's response:

"Usually I will need assistance because some of the words, the Ipad can't really explain much, the teacher can explain to us better." (D:FG3)

Students were asked the question, "How often do you come across reading materials or resources that use a combination of visuals and words in the learning of English?" From the students' responses, the researcher found that these students often come across texts with a combination of visuals and words in the learning of English language. They were then asked the helpfulness of texts with a combination of visuals and words in their learning of English as highlighted in the responses below.

Quite often. Because some of us might not understand the words, we could use the pictures to understand the words. (A:FG3)

Quite often. To me, pictures make texts less wordy and I will be more interested to read them. (B:FG3)

Many of the students stated that texts with visuals help them to comprehend the text better and it induces their interest towards reading the texts. When students are interested to read a text, the teacher will be able to run the lessons much smoothly. 
For the next question, students were asked if they encounter difficulties in interpreting the meaning of posters or texts on websites which include words, animated pictures, still images and sounds. This question was asked to determine the easiness of interpreting MMA based texts and resources. Based on the responses received from the students, it is found that they do not face any difficulties in interpreting posters of multimodal texts as the images and visuals present helps them to make meaning. All of them claimed that if there were only words and descriptions, they may have faced slight difficulties in interpreting the meaning of the posters or texts on websites but with the help of visuals and sounds, they are able to easily make meanings out of such mediums.

4.2 Results on the Benefits of MMA in the Teaching and Learning of ESL

Following that, the students were asked of the frequentness of using texts and handouts consisting only words in their learning of English. They answered in unison that their teacher rarely uses handouts or texts with only words. Some of them commented:

It's very less, because the teacher knows that if it's all words and no pictures, it will be very boring and sometimes, if there are no pictures if will be difficult to understand. (C:FG3)

Not often; If there is text alone, it is not easy because we may not know all the words. When there are pictures, we will know how something will look like. (B:FG2)

In general, students were of the opinion that handouts or texts from books are much interesting to be read in comparison to the entire book. They were heard expressing their disinterest in reading a whole book as they are able to easily look for information needed within a shorter time frame due to the much concise content through given handouts and excerpts from books. One student's comment:

Yes, because it's easier than reading the entire book. People may not have the interest in reading the entire book and handouts are easy, summarised and short. (B:FG1)

When these students were asked if the handouts or texts from books help them in improving their reading and writing skills, all of them thought it was of a great help as they were able to see different styles of writing and learn new vocabularies. It helped them to imitate the style of writing when producing their own texts.

In view of audio design, students were asked the frequentness of their English teacher using music, audio or sound effects in their ESL classroom and its usefulness in helping them understand a text better. Students were then asked to comment whether or not the audio and sound effects used in their ESL lessons were helpful the development of students' listening and speaking skills and they were asked to justify their answers. In relation to this question, two students' responses:

\author{
"Audio helps because many people like me are not visual thinkers, so it helps me to \\ understand." (B:FG1)
}

"Yes, because when we have someone to explain it to us by defining it more, it is easier for us to understand." (D:FG3)

In the next question, students were asked, "Do you find still images and animated images useful in helping you make meaning during ESL lessons? If yes, how? If no, why?" Some students' comments:

Yes, because we can interpret the text better. (A:FG1)

Yes because with pictures, we can use it as shortcuts to remember things. (B:FG1)

Thus, with the help of images and animated images, students are able to make meaning much effectively during ESL lessons. In fact, students claim that they are able to see a bigger picture of a text when images and animated images are used during ESL lessons. In relation to that point, students' were asked of their preferences of reading on screen especially via their Flipped Classroom website and links given by their ESL teacher. A majority of students stated that they prefer on screen reading due to the flexibility of adjusting the size of the texts on screen, portability, accessibility and convenience. Meanwhile, one of them added on that if the texts are too lengthy, it causes tiredness and lack of focus.

In further examining students' thoughts on Spatial Design, they were asked of their opinions on excursions and how they can be helpful in making meaning of new contents in ESL lessons. Based on the students' responses, it is evident that they enjoy excursions and find excursions as an exciting ESL learning activity. 
Yes it will, because if we learn about aeroplane, we will read a lot about aeroplane but if we go for an excursion on aeroplanes, we will know more of how it looks like and how it works. $(B: F G 2)$

Yes because if I just look at a drawing or a text, I wouldn't get so much details about it. But when I go to a museum, I will be able to get a lot of information and details. (E:FG3)

The following question was aimed to explore students' opinions on English lessons involving hands-on activities such as puzzles and games. One student's comment:

Yes, because when we do an English task, if we just write it can sometimes be a little boring, so games and hands on activities will make it more interesting.(E:FG3)

Based on their responses, it is clear that students enjoy games and hands-on activities as a part of their ESL lessons. Apart from the fun factor, such activities in ESL classroom motivate students to learn.

As for gestural design, students were asked if the actions in videos shown during ESL lessons are interesting and help them to make meaning. These are some students' comments:

Yes, because I can understand what they are trying to say through their movements and actions. (D:FG1)

Actually yes it will be useful, let's say we read a text which says a guy is dancing, we wouldn't know how he is dancing or what he did. But if there is a video with the actions of the guy, we will know what he exactly did. (C:FG1)

According to all of them, actions shown in videos helps them in their visualization and thus meaning making becomes easier. When descriptions in the texts are less focused or detailed, it hinders students' understanding of the text. However, we the help of actions shown in videos, students are able to draw out a bigger picture in their minds in relation to the text or topic.

In students' respective focus groups, students were asked, "Do you enjoy role plays and presentations during ESL lessons? If yes, why? If no, why?" In unison, all them stated that they enjoy to be a part of role plays and presentations during ESL lessons as they will be able to experience the characters for themselves. They added on that it helps them to understand a text better when they present it to their classmates via presentations. A student was heard commenting, "Yes, because it's very fun. When our friends are presenting, we get to know each other's point of views.(A:FG3)" Another student remarked, "I enjoy presentations and role plays, because it's fun, just like watching TV shows. And we learn. (B:FG3)"

Towards the end of each session, students were asked about their opinions in relation to the Multimodal Design. One of the question was "Does the use of Ipads and laptops help you in improving your reading, writing, listening and speaking skills? If yes, how? If no, why?" As soon as this question was asked, students rapidly made comments and contributed their answers. Some of the students' comments:

Ipads and laptops can help us with English lessons because for listening and speaking, videos help to make us learn correct pronunciations of certain words. For writing, essay writing can be easier because we can check upon our mistakes. (D:FG2)

Yes, Ipads and laptops help us improve our English skills because we can go look for more stories online and get inspired in writing our own stories.(C:FG3)

Yes, because with a laptop I can see the way a text is written and watching a video tells me more about the text. It also gives me a better idea of how to speak and pronounce certain words. Besides, with written text, I need guidance to go through it. But with Ipad and laptops, I can be more independent because I can research by myself and self-learn pronunciations. (B:FG3)

Generally, students were of the opinion that MMA helps them to become more independent in learning and developing language skills. When they were asked in groups, if they find ESL lessons using a combination of images, words, sounds, and videos interesting, all of them stated that they enjoy lessons with the use of a variety of materials and resources. A student (B:FG3) commented, "Yes, because it will be more interesting. In some lessons, the teacher talks a lot and we instantly get bored. But with pictures, videos and music, it will be more fun for us. And we wouldn't get so bored." Students were disinterested towards traditional teaching style of more lecture-based activities and prefer a range 
of activities to keep them engaged. To further strengthen a student's point, another student commented, "It's interesting because with text, pictures, sounds, audio and video, it will attract me to see it and read along. I will be excited and want to learn." (E:FG3)

\section{Discussion}

\subsection{Learners' Engagement and Motivation}

This case study claims that the MMA promotes learner engagement in the teaching and learning process of ESL as the researcher believes that students appear to be positive minded and motivated to learn with the use of MMA resources and materials in the class. According to student A:FG3, "if you keep showing us slideshows, we might get bored. But if you show us videos, slideshows, activities, we will not be so bored and we will be more interested." The findings from students' focus group interview sessions has drawn the researcher to make a claim that students are highly anticipative and participative in MMA based lessons when compared to lessons with the use of single design. The data clearly suggests that students greatly recognise learning resources with additional representations of content in helping them to comprehend and retain the content taught which is multimodal in nature to be more interesting and enjoyable to use. In parallel, Md. Yunus, Salehi and John, (2013) found that learners who often face difficulties in comprehending texts and literary concepts tend to manage such circumstances by using visual aids to facilitate their comprehension of the texts. According to Walsh (2010), students were highly participative in the tasks provided when given a multi-modal task to work on. They have clearly expressed their dislike towards lengthy texts consisting of words alone and commented of having greater enthusiasm towards multimodal resources which involve a combination of modals. For an example, student B:FG1 stated, "No, because it's very difficult to focus if it's a very long passage. We will lose interest." They find videos and other forms of multimodal resources as interesting and engaging as they are able to make meaning with minimal guidance from the teacher. This point is relevant to the statement made by student B:FG1, "I don't think so I need the teacher's assistance very often with the help of the gadgets. If I don't really know something, I can search online."

Similarly, in a research carried out by Kymes in 2005, he found that everywhere around the world, motivated and interested students tend to go online to independently search for information needed (Kaur \& Sidhu, 2007).

\subsection{Self-Directed Learning}

The major benefit of MMA in the teaching and learning of ESL classroom, it promotes students' autonomy and instigates self-directed learning. Based on the data collected from the students, students claimed to require less teachers' facilitation with the use of technological gadgets in the class. Student A:FG3 commented when asked about the need for teacher's assistance when their lessons integrates usage of ICT, "Not really often. For an example, if we want to find spellings, we just have to type it out and it would autocorrect. Another student added on, I think I don't need teacher's assistance that often because some things which the teacher can't do, can be done with the Ipad (C:FG2). These comments reveals the degree of confidence students have in using the ICT tools made available to them during ESL lessons. In a recent study, Asfar and Zainuddin (2015) found that students showed self-directed learning values with the use of ICT to supplement their learning. Similarly, it is also found that the usage of ICT improves students' creativity in dealing with their tasks on a daily basis (Choo, 2007 as cited in Asfar \& Zainuddin, 2015). The researcher believes the students are able to seamlessly interpret and move from various modals and genres to construct meaning on their own. Most students felt they were able to self-correct their spellings and grammars with the use of their mobile devices in the class. In relation to this point, it is found in previous studies that MMA based lessons enable students to discover learning in their most comfortable ways which challenges them to learn in many other different ways moulding them more self-directed and interactive students (Picciano, 2009 as cited in Sankey, Birch \& Gardiner, 2010).

Cooper (2011) has made a point that students' social interaction via cooperative learning, discussions and dialogues as important part of Constructivist Approach as it helps students to construct meaning on their own. This is clearly evident in ESL classes with MMA as students commented on their abilities to collaborate with their classmates with increased efficiency with the use of various medium such as Google Docs, mind maps and many more.

\subsection{Learning Styles}

No learner is of the same in abilities, skills, interests and learning styles. This has made teaching and learning a much complex process as teachers can never deliver the taught content in the same manner to cater all students at once. Thus, there is a need to differentiate the teaching delivery methods and strategies. A few students were heard commenting on ways they learn best and a few of them commended the teacher's use of videos, images and sounds which are some of the mediums which has helped them to learn best. For an example, a student who is an auditory learner commented, "For some people like me, I prefer audiobooks rather than texts with pictures." Another student who is a visual learner commented, "Yes. For a few people like me, I have a hard time imagining the text when I am reading, so the pictures help me to understand better (B:FG2). Multiliteracies help to cater diversity, ensure inclusiveness which encourages intellectual quality and enable students to experience vast learning experiences (Kalantzis \& Cope, 2005). With MMA, students may self-select the learning object, or representation, that best suits their modal preference based on their predominant learning style (Doolittle, McNeill, Terry \& Scheer, 2005 as cited in Sankey, Birch \& Gardiner, 2010). In addition, learners' beliefs and learning preferences of the learning processes determine the success of second language acquisition (Rifkin, 2000 cited in Vayaravasamy \& Abdullah, 2011). Students with poorer comprehension of texts tend to achieve less in ESL when compared to the others. In a study, Solvie and Kloek (2007) found that learner style 
preferences are more dominant amongst lower achieving students, leading to better performances by students with the use of multimodal content, which accommodates a wider range of learning styles.Therefore, this study claims that the use of MMA enable educators to cater to the different learners' needs in ESL learning environments.

\subsection{Students' Perceptions of their ESL Learning Experiences using MMA}

Students' perceptions of their learning experiences using the MMA to acquire their language skills in their ESL classroom were examined qualitatively through focus group interview sessions. The students in this case study experienced the use of new technology such as Ipads and laptops in the classroom as a supplementary tool to second language learning. These technologies aided them in developing literacy skills needed for their real world needs. Findings of this case study enabled students to reflect upon their ESL lessons and their experiences.

Findings of this study reveal that students strongly agreed that texts and handouts with words alone are boring but they prefer handouts from books as it is comparatively shorter in length than books. They too made a point that lengthy texts do not interest them and cause them to lose motivation, be it monomodal or multimodal in nature. Similarly, it is found in a study that students prefer short texts which are not too time consuming and more comprehensive when compared to longer texts (Ghazali, Setia, Muthusamy \& Jusoff, 2009). Besides, students claimed that texts without pictures and images have made their meaning-making process much difficult and they needed extra guidance to interpret such texts. They have not received texts without images in their ESL lessons which made them strongly believe that lessons with a combination of images, words, videos and audios as more interesting, motivating and enjoyable. According to Campbell (1999), learners tend to perform better in academics and cause lesser problems in the class when they are individually motivated to learn. If teachers strive to ensure students' comprehension and understanding in the class, students will feel secured and positively challenged to learn (Eggen \& Kauchak, 1997 as cited in Campbell, 1999). Thus, the use of MMA in the teaching and learning of ESL is clearly uplifting students' intrinsic motivation to acquire English as their second language.

This study highlights students' perceptions about their experiences during ESL lessons which incorporate MMA as more exciting, motivating and promoting cooperative learning and teamwork which eventually made them better learners. The use of Ipads and laptops in class is said to have enhanced students' cooperation and teamwork. Similarly, in a study conducted in 2015 found that iPads improve learning and students' participation in class activities whilst enabling them to collaborate with their peers (Mango, 2015). Besides that, students interests and participation in role plays and presentations have shown their confidence and development of speaking and listening skills. According to Ghazali, Setia, Muthusamy and Jusoff (2009), activities such as dramas, watching films and videos topped the list of preferences amongst ESL students in Malaysia. This is also evident in this study as students expressed activities such as role plays and presentations as fun and enjoyable way of learning English. Some of them addressed their roles as assessors and active participants of their classmates' role plays and presentations as exciting and educational. They added on that they were able to express themselves verbally and enjoy exchanging ideas via presentations during ESL lessons.

In this study, all of them agreed that the use of ipads and gadgets during ESL lessons should be used frequently as they find it convenient to create documents, videos, mind maps and even audios with the help of their gadgets. Whilst working on these outputs of the lessons, they claimed that integration of technology in their learning experiences have greatly benefitted them in the development of their listening, speaking, reading and writing skills. In a case study, computers are found to be an essential part of the teaching and learning in second language lessons and as a way to transfer language skills to the learners (Basheer Nomas, 2012).

A majority of them mentioned that they find applications and online resources interesting although they require some time to become accustomed to using them. They were highly positive towards the use of Ipad applications and willingly learned to use various applications. Besides, all of them spoke highly of the World Wide Web as it offers a myriad of information for them to integrate in their compositions and presentations. A student commented, "Since I know how to surf the internet quite easily, and I know how to cite and summarise, I feel very comfortable using them" (D:FG2). This reflected upon their familiarity and intuitiveness with ICT related matters. The amount of time spent on their mobile devices per day too denotes to their fluency in ICT. These students described activities without the use of ICT or a combination of modals as non-appealing and causes disinterest.

\subsection{Conclusion}

This case study recognizes the fact that MMA promotes students engagement in the teaching and learning of ESL by enhancing their meaning-making abilities with the supplement of ICT as a tool. This study affirms that students' perception of MMA lessons in an ESL classroom is described as highly engaging, self-directed, and learner-centered and promotes meaning-making with minimal guidance from the teachers. In conclusion, this case study promotes teaching and learning experiences that are multimodal in nature to acquire literacy skills necessary for today's world without being restricted to one mode of design.

\section{References}

Annan, E. (2014). Challenges Confronting the Beneficiaries of the Vodafone/ Uew Educational Fund for Future Women Leaders in Science \& Technology in the University of Education, Winneba, Ghana. International Journal Of Education And Research, 2(3), 1-8. Retrieved from http://www.ijern.com/journal/March-2014/46.pdf 
Asfar, N., \& Zainuddin, Z. (2015). Secondary Students' Perceptions of Information, Communication and Technology (ICT) Use in Promoting Self Directed Learning in Malaysia. The Online Journal Of Distance Education And ELearning, 3(4), 78. Retrieved from http://www.tojdel.net/pdf/v03i04/tojdel-volume03-i04-08.pdf

Basheer Nomass, B. (2013). The Impact of Using Technology in Teaching English as a Second Language. ELLS, 3(1). http://dx.doi.org/10.5539/ells.v3n1p111

Baxter, P., \& Jack, S. (2008). Qualitative Case Study Methodology: Study Design and Implementation for Novice Researchers. The Qualitative Report, 13(14), 544-559. Retrieved from http://www.nova.edu/ssss/QR/QR13-4/baxter.pdf

Bearne, E., \& Wolstencroft, H. (2007). Visual approaches to teaching writing. London: Paul Chapman.

Bergmann, J., \& Sams, A. (2012). Flip your classroom. Eugene, Or.: International Society for Technology in Education.

Birks, M., \& Mills, J. (2015). Grounded theory. Los Angeles, Calif.: Sage. Retrieved from: https://books.google.com.my/books?id=G9xtBgAAQBAJ\&printsec=frontcover\#v=onepage\&q\&f=false

Boshrabadi, A. M., \& Biria, R. The efficacy of MMA vs. Print-based texts for teaching reading comprehension skills to iranian high school third graders. International Journal of Language Learning and Applied Linguistics World. 5(1). 365 380. Retrieved from: http://www.academia.edu/9202933.

Campbell, J. (1999). Student discipline and classroom management. Springfield, Ill.: C.C. Thomas Publisher.

Carroll, J. (2011). From Encyclopaedias to Search Engines: Technological Change and its Impact on Literacy Learning. Literacy Learning: The Middle Years, 19(2), 27-34. Retrieved from http://www.alea.edu.au/documents/item/180

Cooper, J. (2011). Classroom teaching skills. Belmonte, CA: Brookes/Cole. Retrieved from https://books.google.com.my/books?id=KJOe3n9pK3wC\&pg=PA91\&dq=constructivist+theory+in+teaching+and+lear ning \&hl=en\&sa $=X \& v e d=0 C B s Q 6 A E w A G o V C h M I s 5 q k s O a j x w I V U F S O C h 3 h D w I u \# v=$ onepage \& $q=$ constructivist $\% 20$ theory\%20in\%20teaching\%20and\%20learning \& $\mathrm{f}=$ false

Cope, B., \& Kalantzis, M. (2000). A Pedagogy of Multiliteracies: Designing social futures. In The New London Group, Multiliteracies: Literacy Learning and the Design of Social Futures (1st ed., pp. 9-42). London: Roultledge.

Cope, B., \& Kalantzis, M. (2000). Introduction: Multiliteracies: the beginnings of an idea. In B. Cope \& M. Kalantzis, Multiliteracies: Literacy Learning and the Design of Social Futures (1st ed., pp. 4-8). London: Roultledge.

Flood, J., Heath, S., \& Lapp, D. (2008). Handbook of research on teaching literacy through the communicative and visual arts. New York: Lawrence Erlbaum Associates. Retrieved from https://books.google.com.my/books?id=cIx4CAAAQBAJ\&pg=PA442\&dq=students+diengagement+towards+print+bas ed+texts\&hl=en\&sa=X\&ved=0CCgQ6AEwAmoVChMIxvmwqpybxwIVhQWOCh2eEQ78\#v=onepage \&q=students\% 20diengagement $\% 20$ towards $\% 20$ print $\% 20$ based $\% 20$ texts $\& \mathrm{f}=$ false

Frost, T. (1999). The Everyday Life of a Household in Cyberspace. Presentation, Beijing, China. www.iso.org/iso/livelinkgetfile?llNodeId $=21581 \& 11$ VolId $=-2000$

Ganapathy, M. (2007). Using the Multiliteracies Approach to Promote Learner Engagement in an ESL Classroom: A Case Study in a Selected School in Penang (Post-Graduate). Universiti Sains Malaysia.

Ganapathy, M. (2011). The Effects of th Multiliteracies Approaches on the Writing Performance of EFL Students in a Chinese School in Penang: Teacher and Student Perceptions (Ph.D). Universiti Sains Malaysia.

Ganapathy, M. (2014). Using Multiliteracies to Engage Learners to Produce Learning. IJEEEE, 4(6). http://dx.doi.org/10.17706/ijeeee.2014.v4.355

Ghazali, S., Setia, R., Muthusamy, C., \& Jusoff, K. (2009). ESL Students' Attitude towards Texts and Teaching Methods Used in Literature Classes. English Language Teaching, 2(4). http://dx.doi.org/10.5539/elt.v2n4p51

Gill, P., Stewart, K., Treasure, E., \& Chadwick, B. (2008). Methods of data collection in qualitative research: interviews and focus groups. BDJ, 204(6), 291-295. doi:10.1038/bdj.2008.192

Gumbo, M. (2014). An Action Research Pilot Study on the Integration of Indigenous Technology in Technology Education. MJSS. doi:10.5901/mjss.2014.v5n10p386

Gunderson, L. (2009). ESL (ELL) literacy instruction. New York: Routledge. Retrieved from https://books.google.com.my/books?id=nak3AAAAQBAJ\&pg=PA239\&dq=ESL+and+Literacy\&hl=en\&sa=X\&ved=0 CC8Q6AEwAmoVChMI9eqxlZihxwIVx5COCh0syADC\#v=onepage\&q=ESL\%20and\%20Literacy\&f=false

Hagood, M. (2003). New Media and Online literacies: No Age Left Behind. Reading Research Quarterly, 38(3). Retrieved from http://www.jstor.org/stable/4151825

Jewitt, C. (2008). Multimodality and Literacy in School Classrooms. Review Of Research In Education, 32(1), 241-267. doi:10.3102/0091732x07310586

Kaur, S., \& Ganapathy, M. (2014). Multiliteracies in Education: Concept and Focus. In S. Kaur \& S. Abdul Manan, Contemporary Perspectives in English Language Studies: Linguistics and Literature (1st ed., pp. 152-167). Penang: Universiti Sains Malaysia Press. 
Kaur, S., \& Wong, C. (2011). Transforming ESL Teaching by Embedding Infomration and Web Literacies into the Classroom. In A. Pandian, T. Chow \& S. Mohamed Ismail, Curriculum Development, Materials Design and Methodologies: Trends and Issues (1st ed.). Penang: Universiti Sains Malaysia Press.

Kalantzis, M., \& Cope, B. (2005). Learning by design. Melbourne, Aus.: Victorian Schools Innovation Commisstion.

Kress, G. (2009). Multimodality. Hoboken: Taylor \& Francis.

Luan, L., \& Wang, H. (2009). The Impact of Second Language Proficiency on Chinese ESL Students' English Word Recognition. Asian Social Science, 5(1). doi:10.5539/ass.v5n1p37

Malaysian Communication and Multimedia Commission,. (2015). STATISTICAL BRIEF NUMBER SEVENTEEN: HAND PHONE USERS SURVEY 2014 (pp. 12-44). Selangor: Malaysian Communication and Multimedia Commission. Retrieved from http://www.skmm.gov.my/skmmgovmy/media/General/pdf/Hand-Phone-User2014.pdf

Manan, S. (2012). Linguistics, Literature and Culture. Newcastle upon Tyne: Cambridge Scholars Pub.

Mango, O. (2015). Ipad Use and Student Engagement in the Classroom. The Turkish Online Journal Of Educational Technology, 14(1), 53-57. Retrieved from http://www.tojet.net/articles/v14i1/1417.pdf

Manyasi, B. (2014). The Ethical Dilemma in Educational Research. Journal Of Education And Literature, 2(2), 68. Retrieved from http://www.rassweb.com/wp-content/uploads/PDF/JEL/Vol-2/Issue-2/Paper\%204.pdf

Marlowe, B., \& Page, M. (1998). Creating and sustaining the constructivist classroom. Thousand Oaks, Calif.: Corwin Press.

Martin, T. (2006). Qualifications in Education for TAFE lecturers in Western Australia: Background, Functions and Concerns (Ph.D). University of Western Australia. Retrieved from http://www.uwa.edu.au/_data/assets/rtf_file/0010/99856/Martin_Theresa_EdD.rtf

Md. Shah, P., \& L. Empungan, J. (2014). ESL Teachers' Attitudes towards Using ICT in Literature Lessons. IJELE, 3(1), 201. doi:10.5296/ijele.v3i1.7158

Mehrabi Boshrabadi, A., \& Biria, R. (2014). The efficacy of MMA vs. print-based texts for teaching reading comprehension skills to Iranian high school third graders. International Journal Of Language Learning And Applied Linguistics World, 5(1), 365-380. Retrieved from http://www.ijllalw.org/finalversion5130.pdf

Mikulecky, L., \& Kirkley, J. (1998). Literacy Instruction for the 21st-Century Workplace. Peabody J. Of Educ., 73(3), 290-316. doi:10.1207/s15327930pje7303\&4_14

Ministry of Education Malaysia. (2012). Preliminary Report: Malaysia Education Blueprint 2013-2025. Ministry of Education Malaysia.

Mohd Ghani, M., Mahmood, F., Abdul Halim, H., \& Rajindra, S. (2013). The Impact of Technology on Reading Texts Selection among Upper secondary ESL Students. International Journal Of Humanities Social Sciences And Education (IJHSSE) Volume, 1(3), 15. Retrieved from https //www.arcjournals.org/pdfs/ijhsse/v1-i3/3.pdf

Neville, M. (2005). Innovation in Queensland Education: Multiliteracies in Action. In M. Kalantzis \& B. Cope, Learning by Design (1st ed., pp. 231-256). Melbourne: Common Ground Publishing Pty Ltd.

O'Rourke, M. (2005). Multiliteracies for 21 st century schools. Australian National Schools Network, Faculty of Education, University of Technology, Sydney.

Pathak, A \& Intratat, C. (2012). Use of Semi-Structured Interviews to Investigate Teacher Perceptions of Student Collaboration. Malaysian Journal of ELT Research, 8 (1), 1-10. Retrieved from www.melta.org.my

Pathak, R. (2008). Methodology of educational research. New Delhi: Atlantic Publishers \& Distributors. Retrieved from

https://books.google.com.my/books?id=OANf7tHNhwAC\&printsec=frontcover\&dq=purpose+of+research+in+educatio n\&hl=en\&sa=X\&ved=0CDoQ6AEwBmoVChMIz9Xyg Y2qxwIVkBiOCh2TQwqi\#v=onepage \&q=purpose\%20of\%20r esearch\%20in\%20education \&f=false

Reyes, S., \& Vallone, T. (2008). Constructivist strategies for teaching English language students. Thousand Oaks, CA: Corwin Press.

Rush, L.S. (2003). Taking a broad view of literacy: Lessons from the Appalachian Trail thru-hiking

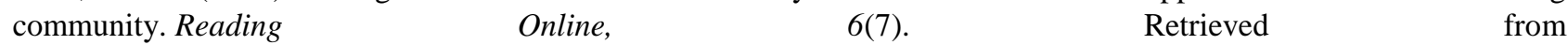
http://www.readingonline.org/newliteracies/lit_index.asp?HREF=rush/

Sankey, M., Birch, D., \& Gardiner, M. (2010). Engaging students through multimodal learning environments: The journey continues. In Ascilite 2010 (pp. 852-861). Sydney: Ascilite. Retrieved from http://www.ascilite.org.au/conferences/sydney10/procs/Sankey-full.pdf

Siemens, G. (2014). Connectivism: A learning theory for the digital age. Retrieved from http://www. itdl. org/journal/jan_05/article01. Htm

Solvie, P., \& Kloek, M. (2007). Using Technology Tools to Engage Students with Multiple Learning Styles in a Constructivist Learning Environment. Contemporary Issues In Technology And Teacher Education, 7(2), 7-27. Retrieved from http://www.editlib.org/p/22811/ 


Subramaniam, B. (2015). On the social media circuit. The Star. Retrieved from
http://www.thestar.com.my/News/Education/2014/01/05/On-the-social-media-circuit/

Tyner, K. (1998). Literacy in a digital world. Mahwah, N.J.: L. Erlbaum Associates. Retrieved from https://books.google.com.my/books?id=Cc-QAgAAQBAJ\&printsec=frontcover\#v=onepage\&q\&f=false

Vayaravasamy, P., \& Abdullah, A.C. (2011). Students' and Teachers' Preferences of ESL Classroom Activities. In A. Pandian, T. Chow \& S. Mohamed Ismail, Curriculum Development, Materials Design and Methodologies: Trends and Issues (1st ed.). Penang: Universiti Sains Malaysia Press.

Yunus, M. M., Salehi, H., \& John, D. S. A. (2013). Using Visual Aids as a Motivational Tool in Enhancing Students Interest in Reading Literary Texts. arXiv preprint arXiv:1305.6360.

Walsh, M. (2010). Multimodal literacy: What does it mean for classroom practice?. Australian Journal Of Language And Literacy, 33(3), 211-239. Retrieved from https://www.alea.edu.au/documents/item/63

Wrigley, H., \& Guth, G. (1992). Bringing literacy to life. San Mateo, CA: Aguirre International for the U.S. Dept. of Education, Office of Vocational and Adult Education. 